\title{
ANALISIS WACANA JURNALISME KEBERAGAMAN DALAM PEMBERITAAN KAWASAN KULINER PECINAN (KKP) DI HARIAN FAJAR
}

\author{
DIAN MUHTADIAH HAMNA, MUH. TAHIR \\ Fakultas Ilmu Sosial dan Politik \\ Universitas Muhammadiyah Makassar \\ Email : dianmuhtadiah@yahoo.com, tahirmuh1963@gmail.com
}

\begin{abstract}
:
In the era of democracy, the issue of diversity becomes interesting to be discussed given the importance of maintaining the integrity of the Unitary Republic of Indonesia (NKRI). One of the roles of the media is to be a bridge to convey the discourse of diversity in a pluralist Indonesian society. Through diversity journalism, the media has a role in bringing messages of peace and not confusing the atmosphere of conflict through reporting. News dictionaries play an important role in constructing people's perception of an event. One of the diversity journalism was applied by Fajar Daily through the reporting of the Chinatown Culinary Area (KKP) in Makassar. The consistency of peaceful reporting makes the area visited by interethnic residents. The long-term goal of this research is to find out how diversity journalism reconstructs people's perceptions so that they are motivated to create harmony in the midst of multipluralism. It also serves as a guide for the media and journalists in maintaining messages of peace through the news. While the specific target to be achieved is to test the agenda-setting theory and the theory of discourse analysis in the preaching of the KKP in Fajar Daily.
\end{abstract}

Keywords : Diversity Journalism; Chinatown Area; Discourse Analysis

\section{PENDAHULUAN}

Keberagaman, kemajemukan, atau pluralitas menjadi salah satu isu yang mengemuka sejak Indonesia memasuki era reformasi, atau dalam literatur politik disebut era transisi menuju demokrasi (transition to democracy) atau transisi demokrasi (democratic transition). Penyebabnya antara lain di era yang relatif lebih demokratis dibanding masa Orde Baru ini, identitas mengalami penguatan atau penegasan.

Penegasan identitas, baik suku, agama, ras, maupun gender, ibarat dua sisi mata uang. Ia bisa menunjukkan berapa Indonesia semakin kaya dengan etnis, kultur, bahasa, dan agama. Penegasan identitas itu bisa menjadi sarana untuk saling mengenal, saling menghargai, dan saling bertoleransi. Penguatan identitas dalam konteks ini bisa mempromosikan keberagaman.

Tetapi, penguatan identitas itu bisa juga memicu konflik, gesekan dan 
pertikaian. Penegasan identitas justru memperjelas siapa kita dan siapa mereka. Kelompok arus utama mungkin saja merasa terancam oleh kelompok-kelompok kecil dan pinggiran yang mulai memperlihatkan eksistensi dan ekspresi mereka. Kelompok-kelompok pinggiran sendiri merasa berhak mengekspresikan identitas mereka seluas-luasnya.

Kansong dalam Jurnalisme Keberagaman (2016) mengatakan, faktanya, alih-alih menciptakan keberagaman, penguatan identitas lebih banyak memicu pertikaian. Intoleransi terhadap kelompok lain cenderung meningkat. Misalnya Basuki Tjahaja Purnama atua Ahok mendapat perlakuan diskriminatif menjelang Pilkada DKI 2017. Banyak kalangan yang melakukan black campaign untuk tidak memilih Ahok sebagai Gubernur DKI periode 2017-2022 karena dia beretnis Tionghoa dan beragama Kristen. Ahok "diserang" etnis dan agamanya, bukan program atau perilakunya.

Diskriminasi dalam bentuk ancaman verbal menimpa kalangan LGBT. Rektor Universitas Sumatera Utara, Runtung Sitepu, misalnya mengancam memecat mahasiswa LGBT karena orientasi seksual yang melekat dalam diri mereka, bukan karena bodoh, malas atau melakukan perbuatan kriminal. Sehingga tidak mengherankan apabila konflik horizontal di era reformasi lebih luas dan lebih keras dibanding konflik di masa Orde Baru atau masa-masa sebelumnya.

Jurnalisme sebagai salah satu dari empat pilar demokrasi, juga salah satu dari lima arena konsolidasi demokrasi, semestinya berkontribusi mewujudkan sisi mata uang keberagaman yang mendorong pemahaman atas yang lain. Serta meminimalkan sisi mata uang pertikaian yang diakibatkan oleh menguatnya identitas di masa transisi demokrasi ini.

Sayangnya, jurnalisme belum sepenuhnya mengambil peran tersebut. Peliputan mengenai isu keberagaman belum banyak dilakukan secara konsisten oleh media di Indonesia. Hal ini karena belum adanya panduan memadai yang bisa menjadi pedoman bagi mereka yang berkiprah di dunia pers atau media untuk mempraktikkan apa yang kemudian disebut jurnalisme keberagaman.

Padahal, media sebagai front terdepan dalam membangun pilar demokrasi harus memelihara isu keberagaman sebagai ruh yang penting dalam pemberitaan. 
Mengingat banyaknya kelompok etnik, kelompok agama dan kelompok-kelompok lainnya dari Sabang sampai Merauke. Lewat pemberitaan, media harus memposisikan diri dalam kondisi netral sekaligus pendamai. Media yang memiliki powerfull harus menjadi penyejuk dalam situasi genting karena pola pikir masyarakat juga ditentukan oleh pemberitaan media.

Salah satu jurnalisme keberagaman diterapkan Harian Fajar melalui pemberitaan Kawasan Kuliner Pecinan (KKP). Kawasan ini digagas oleh koran tersebut bersama Pemerintah Kota Makassar, Honda, Yayasan Budi Luhur, Perhimpunan Indonesia Tionghoa (INTI) dan Paguyuban Sosial Marga Tionghoa Indonesia (PSMTI) sejak Februari 2016 lalu.

Kawasan yang terletak antara pertemuan Jalan Bali dan Jalan Bonerate, Kecamatan Wajo, Kota Makassar ini berada di pusat permukiman warga Tionghoa. Menariknya, aneka penganan yang dijajakan tidak hanya berupa makanan tradisional Tionghoa seperti Tahu Ma Po, Jiaozi, Won Ton, dan sebagainya tetapi juga penganan tradisional warga pribumi (Bugis-Makassar) seperti Pisang Ijo, Pallu Butung, Barongko, dan lain-lain. Untuk menikmati aneka kuliner yang diracik dari etnis berbeda ini, pengunjung bisa hadir setiap Sabtu pukul 17.00-23.00.

Agar suasana makin meriah, pengelola KKP menciptakan beragam kreativitas agar pengunjung tertarik ke kawasan ini. Misalnya menghadirkan Putri Indonesia 2016, Kezia Roslin Cikita Warouw dengan diiringi Tari Singa atau Barongsai, menggelar lomba karaoke lagu berbahasa Mandarin, menggelar kejuaraan Panco Walikota Cup 1, dan sebagainya. (Harian Fajar, 5 Februari 2017).

Kehadiran KKP telah menyulap kawasan Jalan Bonerate dan Jalan Bali menjadi lebih ramai dengan konsep culture street. Warga setempat yang dahulu pesimis melihat kawasan ini sepi, sekarang telah berbaur dan mendukung terciptanya kawasan culture street tersebut seperti yang diungkap Camat Wajo, Ansaruddin. (Harian Fajar, 18 April 2016).

Selain itu, KKP dihadirkan sebagai salah satu destinasi wisata kuliner di Kota Anging Mammiri berbasis kultur. Sesuai perencanaan, kuliner yang dibawa 
masuk pedagang pun bernilai tinggi karena harus menarik, bersih dan higienis. (Harian Fajar, 12 Maret 2016).

Kehadiran KKP di Kota Makassar secara langsung memberikan warna pemberitaan tersendiri bagi Harian Fajar dalam menerapkan jurnalisme keberagaman. Konsisitensi pemberitaan berbasis jurnalisme keberagaman adalah upaya mendukung keutuhan Negara Kesatuan Republik Indonesia (NKRI) agar terhindar dari paham-paham radikal dan intoleransi.

Berdasarkan fenomena di atas, maka penulis tertarik melakukan penelitian "Analisis Wacana Jurnalisme Keberagaman dalam Pemberitaan Kawasan Kuliner Pecinan (KKP) di Harian Fajar"

\section{TINJAUAN TEORITIS}

\section{Jurnalisme Keberagaman}

Indonesia adalah masyarakat majemuk yang multikultural, yaitu suatu masyarakat yang terdiri dari kelompok-kelompok yang berbeda berakulturasi dengan menghargai pluralisme sebagai keragaman budaya untuk tetap dilestarikan. Kemajemukan ditandai tersebut ditandai oleh adanya suku-suku bangsa yang masing-masing mempunyai cara-cara hidup atau kebudayaan yang berlaku dalam masyarakat suku bangsanya sehingga mencerminkan adanya perbedaan dan pemisahan antara etnik yang satu dengan lainnya, tetapi secara bersama-sama hidup dalam satu wadah masyarakat Indonesia. Kebudayaan tersebut juga berupa ritual-ritual sistem kepercayaan yang bahkan masih dipegang teguh hingga saat ini.

Menurut Suparlan dalam Mayopu (2015) perbedaan tersebut pada hakikatnya adalah perbedaan-perbedaan yang disebabkan oleh sejarah perkembangan kebudayaan masing-masing. Puncak-puncak kebudayaan tersebut adalah kon? ?igurasi yang masing-masing kebudayaan memperlihatkan adanya pinsip-prinsip kesamaan dan saling penyesuaian satu dengan lainnya sehingga menjadi landasan bagi terciptanya kebudayaan nasional.

Jurnalisme keberagaman sendiri memiliki tiga prinsip, yakni mengedukasi, mengadvokasi, dan berempati. Mengedukasi artinya mendidik dan mencerahkan 
audiens sehingga audiens kelak memiliki pola pikir yang berpihak pada keberagaman. Prinsip advokasi menandai bahwa jurnalisme keberagaman memiliki misi "membela" korban intoleransi atau diskriminasi atau sikap-sikap antikeberagaman lainnya. Sedangkan berempati mengandung makna jurnalisme keberagaman mesti menempatkan diri dalam posisi mereka yang menjadi korban tindakan antikeberagaman.

Sebagai turunan dari ketiga prinsip tersebut, jurnalisme keberagaman memiliki sejumlah karakteristik. Karakteristik tersebut adalah berpihak pada keragaman dan perbedaan, berpihak pada korban, berpihak pada minoritas, sensitif gender, menjunjung Hak Asasi Manusia (HAM) dan berperspektif jurnalisme damai. Jurnalisme keberagaman mengedepankan inklusivisme, pluralisme, dan multikulturalisme serta mendorong toleransi.

Kansong (2016) menyatakan bahwa keberpihakan pada keberagaman menyuratkan penolakan kepada upaya kontraproduktif terhadap keberagaman tersebut. Oleh karena itu, jurnalisme keberagaman menolak diskriminasi etnis, ras, gender, dan agama serta menentang radikalisme, intoleransi, dan ekslusivisme.

Penolakan di sini bukan berarti jurnalisme keberagaman tidak memberitakan peristiwa kekerasan atau intoleransi dari satu kelompok ke kelompok lainnya. Jurnalisme keberagaman tetap memberitahukan dengan sejumlah tujuan. Pertama, menginformasikan kepada khalayak ramai dan negara bahwa masih terjadi peristiwa kekerasan dan toleransi yang perlu mendapat perhatian pihak berwenang. Kedua, menyajikan berita berperspektif kritiskonstruktif terhadap radikalisme dan intoleransi.

Dalam tataran teknis, diksi menjadi penting untuk menunjukkan keberpihakan pada keragaman dan perbedaan. Pers berperspektif keberagaman tentu akan sangat selektif dalam memilih kata, ungkapan, atau terminologi. Dalam pemberitaan kasus Cikeusik, pers berperspektif keberagaman tidak akan menggunakan diksi "bentrok", tetapi "penyerangan". Penyebabnya, bahwa ada kelompok yang menyerang pengikut Ahmadiyah di Cikeusik, Banten. Media berperspektif keberagaman, dalam konteks Ahmadiyah, Syiah, agama lokal atau 
agama minoritas, juga akan menghindari menggunakan kata "sesat" melainkan berbeda.

\section{Kawasan Kuliner Pecinan (KKP) dalam Pemberitaan Harian Fajar}

Harian Fajar yang berpusat di Lantai 4 Gedung Graha Pena, Jalan Urip Sumoharjo No 20 Makassar merupakan media cetak terbesar di Kawasan Timur Indonesia (KTI). Tiras media ini mencapai 33.000 eksamplar per hari dengan distribusi 24 kabupaten/kota di Sulsel dan sejumlah wilayah di KTI. Setiap hari, media yang berada di bawah naungan Jawa Pos Group ini memproduksi kurang lebih 100 berita. Berita-berita tersebut terbagi pada berbagai rubrikasi seperti Nasional, Internasional, Politik, Ekonomi Bisnis, Kesehatan, Entertainment, Metropolis, Zetizen, dan lain-lain. Media ini didirikan oleh Alwi Hamu yang merupakan jurnalis senior Sulawesi Selatan pada tanggal 1 Oktober 1981. Kini, Harian Fajar memiliki kurang lebih 80 jurnalis yang memproduksi berita aktual setiap hari baik versi cetak maupun versi online.

Harian Fajar tidak hanya hadir memenuhi kebutuhan informasi bagi pembaca di Sulawesi Selatan dengan mengedepankan akurasi dan akualitas, tetapi juga aktif melakukan inovasi dengan menggelar berbagai event agar makin dekat dengan pembacanya.

Salah satu terobosan yang dilakukan Harian Fajar adalah dengan membuka Kawasan Kuliner Pecinan (KKP) yang disambut baik oleh Pemerintah Kota Makassar, Honda, Yayasan Budi Luhur, Perhimpunan Indonesia Tionghoa (INTI) dan Paguyuban Sosial Marga Tionghoa Indonesia (PSMTI). Kawasan yang dibuka sejak Februari 2016 lalu ini berlokasi di dua pertemuan jalan yakni Jalan Bali dan Jalan Bonerate, Kecamatan Wajo, Kota Makassar. Kawasan ini merupakan pusat permukiman warga Tionghoa. Sebelum KKP hadir, kawasan ini sepi dan tidak ada aktivitas berarti bagi warga sekitar. Namun, setelah KKP hadir yang diisi dengan 100 pelaku usaha kecil menengah, kawasan ini menjadi salah satu destinasi kuliner di Kota Makassar.

Kehadiran KKP tidak hanya mendorong kebauran antaretnis di kawasan tersebut, tetapi berimbas pada peningkatan ekonomi kerakyatan. Hal ini terlihat pada tingkat kenaikan pengunjung pada hotel yang berada di sekitar lokasi. Sebab, 
ada pengunjung yang berasal dari luar daerah ingin turut menikmati wisata kuliner di KKP. Misalnya Hotel Tiara Sari Indah. (Harian Fajar, 18 April 2016).

Pemberitaan mengenai aktivitas di KKP rutin dipublikasikan Harian Fajar sejak tahun 2016 hingga sekarang. Pemberitaan tersebut terakomodasi di rubrik Around Makassar. Selain berita, juga dilengkapi dengan beragam gambar menarik sehingga pemberitaan semakin dinamis. Berikut salah satu contoh pemberitaan KKP :

Harian Fajar edisi Sabtu, 28 Mei 2016, Hal. 14, rubrik Around Makassar

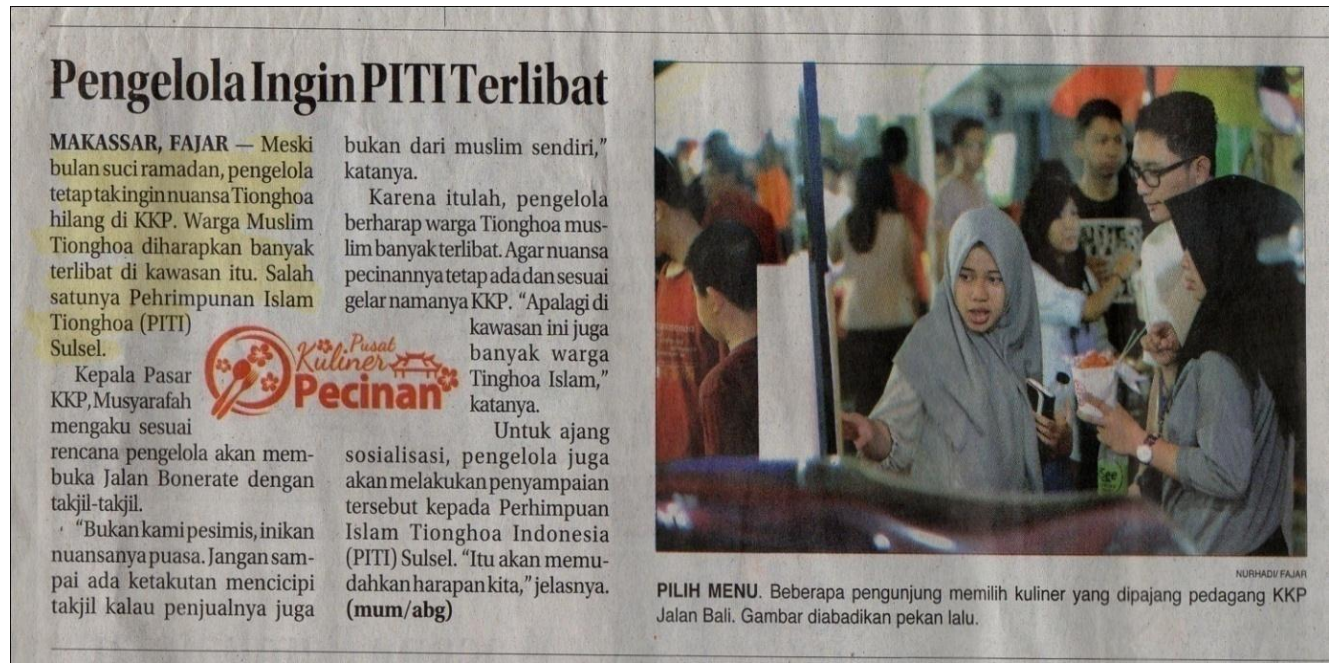

Tampak dari berita di atas, terdapat pesan simbolik dari wacana atau teks berita yang dipaparkan. Pesan simbolik tersebut dapat berupat tema atau ide pokok sebuah teks sebagai isi utama dan konteks sebagai isi laten. Dalam penelitian ini, pesan-pesan simbolik tersebut ialah aspek-aspek sosial, ekonomi, politik dan etnik yang memengaruhi terbentuknya wacana tersebut.

\section{Teori Agenda Setting}

Elfi Yanti Ritonga (2018) menyatakan bahwa teori agenda setting ini banyak dipakai dalam penelitian oleh para peneliti yang ingin mengukur pengaruh media bagi khalayak. Dua asumsi dasar yang paling mendasari penelitian tentang penentuan agenda setting adalah : 1) masyarakat pers dan media massa tidak mencerminkan kenyataan, mereka menyaring dan membentuk isu, 2) konsentrasi media massa hanya pada beberapa masalah masyarakat untuk ditayangkan sebagai isu-isu yang lebih penting daripada isu-isu lain. 
Adapun pengertian agenda setting dalam istilah komunikasi adalah: a) Maxwell E. McCombs dan Donald L. Shaw percaya bahwa media massa memiliki kemampuan untuk mentransfer hal yang menonjol yang dimiliki sebuah berita dari news agenda mereka kepada public agenda. Pada saatnya, media massa mampu membuat apa yang penting menurutnya, menjadi penting pula bagi masyarakat. b) Menurut Bernard C. Cohen, agenda setting theory adalah teori yang menyatakan bahwa media massa berlaku merupakan pusat penentuan kebenaran dengan kemampuan media massa untuk mentransfer dua elemen yaitu kesadaran dan informasi ke dalam agenda publik dengan mengarahkan kesadaran publik serta perhatiannya kepada isu-isu yang dianggap penting oleh media massa. Dikemukakannya bahwa "pers mungkin tidak berhasil banyak waktu dalam menceritakan orang-orang yang berpikir, tetapi berhasil mengalihkan para pemirsa dalam berpikir tentang apa”.

\section{Teori Analisis Wacana}

Hamad (2007) menyatakan untuk memahami dan menerapkan analisis wacana, sebaiknya diresapi dulu hubungan antara teori dan analisis wacana. Sebagai sebuah pendekatan penelitian, analisis wacana memiliki sejumlah metode analisis wacana dan pada awalnya, metode-metode analisis wacana itu adalah teori wacana, bahkan adalah teori sosial. Teori wacana sendiri adalah bidang kajian linguistik sehingga untuk mendapatkan hasil analisis wacana diperdalam teori wacana yang relevan dengan metode yang dipergunakan.

Sebagai contoh, salah satu metode analisis wacana adalah semiotika. Sejatinya, semiotika adalah salah satu teori linguistik yang bernama teori semiotika, sehingga jika kita menggunakan metode semiotika sangat dianjurkan mempelajari teori semiotika. Metode lain yang bersumber dari teori bahasa adalah semiotika sosial, sedangkan CDA (critical discourse analysis) lebih dekat dengan sosio-linguistik. Metode lain, analisis framing, analisis sesiologi, analisis Marxis berasal dari teori-teori sosial (sosiologis), sementara psikoanalisis sebagai metode adalah teori psikologi aliran psikoanalisis.

Analisis wacana CDA menggunakan dua model yakni CDA model Norman Fairclough yang melihat teks (naskah) memiliki konteks dan CDA dari 
Ruth Wodak yang menilai teks (naskah) mempunyai sejarah. Dalam penelitian ini, penulis memilih model CDA Norman Fairclough. Model ini sekaligus memberi implikasi bahwa dalam memahami wacana (naskah/teks) kita tak dapat melepaskan dari konteksnya. Untuk menemukan "realitas" di balik teks kita memerlukan penelusuran atas konteks produksi teks, konsumsi teks, dan aspek sosial budaya yang memengaruhi pembuatan teks.

\section{METODE PENELITIAN}

Peneliti mengandalkan interpretasi dan penafsiran. Hal tersebut sesuai dengan analisis wacana yang merupakan bagian dari metode interpretatif. a. Memfokuskan pada pesan yang tersembunyi (latent). Hal tersebut dilakukan karena banyak teks komunikasi yang ditemukan yang penyampaiannya secara implisit. Oleh sebab itu, makna suatu pesan harus pula dianalisis dari sudut makna yang tersembunyi.

b. Peneliti tidak hanya menganalisis dalam level makro (isi dari suatu teks) tetapi juga pada level mikro yang menyusun suatu teks, seperti kata, kalimat dan retoris.

c. Peneliti tidak bermaksud melakukan generalisasi. Hal tersebut didasari oleh asumsi: (a) setiap peristiwa pada dasarnya selalu bersifat unik; dan (b) peristiwa atau isu yang diteliti juga memiliki konteks dan relasi sosial yang berbeda-beda.

Pendekatan analisis yang digunakan ialah pendekatan kritis, yaitu pendekatan yang memusatkan perhatian terhadap pembongkaran aspek-aspek yang tersembunyi di balik sebuah kenyataan yang tampak (virtual reality) guna dilakukannya kritik dan perubahan (critique and transformation) terhadap struktur sosial. Kerangka analisis tersebut dipilih karena peneliti berusaha menutupi kekurangan analisis isi yang hanya menekankan pada pesan yang tampak, kurang memperhatikan konteks (tidak membahas latent content) dan mengabaikan makna simbolis pesan, sehingga tidak ditemukan pesan yang sesungguhnya dari sebuah teks. Dalam hal ini, berkenaan dengan apa yang telah dilakukan oleh surat kabar dalam memosisikan jurnalisme keberagaman. 


\section{PEMBAHASAN}

Dalam alur kerja redaksional, sulit dipisahkan apa yang dinamakan "kepentingan". Kepentingan di sini adalah sebagian dari apa yang disebut kemauan atau keinginan atau perencanaan, atau agenda penerbit atau redaksi atau orang-orang seorang anggota redaksi. Tiap media massa mempunyai agenda untuk penerbitan berikutnya, yang biasanya ditentukan di dalam rapat. Tapi tidak jarang, pemimpin redaksi sendiri secara khusus menempatkan satu atau dua perencanaan tertentu yang dianggapnya sangat penting. (Sinansari, 2007).

Pada teori Agenda Setting, nyata kelihatan adanya dua perencanaan. Pertama, perencanaan yang dibuat oleh redaksi media yang bersangkutan dan disebut agenda media. Kedua, perencanaan "yang dibuat" oleh khalayak dan disebut agenda publik. Agenda publik ini bentuknya abstrak, yang bisa agak konkret bila dicari dengan penelitian. Sebaik-baiknya agenda media adalah yang kurang lebih sama dengan agenda publik hingga apa yang diinginkan atau dikehendaki oleh publik (khalayak) yang diperoleh atau didapat dalam media massa. Pada posisi yang demikian, dapat diibaratkan media itu seperti ikan sedang khalayaknya adalah air. Ikan tanpa air tidak akan dapat hidup. Agenda media jangan sampai jauh melenceng dari agenda publik kalau media yang bersangkutan tidak ingin ditinggalkan oleh khalayak.

Fungsi agenda setting menurut Lang \& Lang, media massa memiliki kekuatan untuk memberi perhatian terhadap isu tertentu. Mereka dapat membangun citra publik mengenai seorang figur. Media massa dapat pula secara konstan menampilkan obyek tertentu untuk memberi sugesti terhadap individu agar mau berpikir tentang sesuatu, mengetahui sesuatu, dan memiliki perasaan tertentu tentang sesuatu.

Agenda setting itu juga diterlihat dalam pemberitaan Kawasan Kuliner Pecinan (KKP) di Harian Fajar. Koran yang didirikan oleh HM Alwi Hamu itu menempatkan pemberitaan KKP setiap hari Minggu di halaman Around Makassar. Hal ini berlangsung sejak tahun 2016 hingga sekarang. Tidak jarang tim redaksi Harian Fajar menampilkan pemberitaan KKP dengan space $1 / 2$ halaman ditunjang foto-foto dan berita. Penerapan agenda setting ini diakui oleh Reporter Harian 
Fajar, Muhlis Majid yang setiap pekan meliput aktivitas masyarakat di KKP. Menurutnya, agenda setting pemberitaan KKP dimulai dari level perencanaan hingga penugasan kepada reporter. Bahkan, angle peliputan atau sudut pandang pengambilan isu berita juga diarahkan sesuai keinginan editor yang telah lebih dahulu berperspektif jurnalisme keberagaman.

"Khusus liputan KKP, editor selalu mengingatkan reporter tentang keberagaman. Karena KKP dihadirkan memang dengan tujuan agar pribumi dengan etnis lainnya bisa berbaur. Khususnya dengan warga Tionghoa. Kami diarahkan untuk mencari sesuatu yang menarik dan diusahakan agar beritanya positif yang bisa mengangkat KKP agar selalu ramai," (Wawancara Muhlis Majid, 1 Maret 2018).

Diakui Muhlis Majid, pemberitaan positif mengenai KKP itu berimbas kepada tingkat ketertarikan pengunjung ke lokasi ini. Sebab, pembauran antar etnis yang digambarkan dalam berita-berita KKP, akan membuat masyarakat ke tempat ini merasa aman. Kendati demikian, Muhlis Majid berusaha untuk tetap menjaga independensinya sebagai jurnalis ketika bekerja di lapangan. Nilai-nilai jurnalisme keberagaman yang telah ditularkan dari editor Harian Fajar, coba diterapkan di lapangan dengan upaya menjaga berita tetap terkonfirmasi dengan baik, berimbang, dan selalu menghindari berita yang berbau SARA.

Editor Harian Fajar lainnya, Hamdani Saharuna serta Yusriadi mengakui bahwa di Harian Fajar, mereka telah dibekali idealisme nilai-nilai keberagaman. Sehingga ketika menugaskan reporter, mindset itu telah tertanam dibenak mereka bahwa dalam peliputan, hendaknya jurnalis tidak membeda-bedakan narasumber hanya karena perbedaan agama.

"Pemahaman akan keberagaman ini dalam jurnalistik diharapkan dapat menggugah kesadaran bahwa keberagaman merupakan suatu hal yang mutlak dan sangat terkait akan Hak Asasi Manusia. Utamanya bagi kaum minoritas yang kerap menjadi korban dalam suatu permasalahan di tengah masyarakat," (Wawancara Hamdani Saharuna, 1 Maret 2018).

Dari kasus ini, terlihat bahwa Harian Fajar yang bertagline Bijak di Garis Tak Berpihak tidak hanya sekadar slogan. Namun implementasinya dijabarkan di tingkat redaksi mulai level pimpinan redaksi hingga reporter dalam mengangkat isu tertentu seperti pemberitaan KKP. Menurut analisis penulis, hal ini penting untuk menjaga irama pemberitaan KKP tetap positif. Masyarakat yang membaca berita tersebut merasa bahwa kawasan ini memang layak dikunjungi. Jika ini 
terjadi, maka yang diuntungkan adalah Harian Fajar sendiri. Dari sisi kepercayaan, Harian Fajar selaku salah satu penggagas kehadiran KKP akan mendapatkan reputasi yang baik di mata masyarakat. Citra positif diperlukan oleh sebuah media cetak agar bisa bertahan di era digital saat ini. Dan, itu bisa dibangun dari konten pemberitaan yang berkualitas. Dari sisi bisnis, juga akan meningkatkan jumlah pengiklan dari Harian Fajar minimal yang berasal dari etnis Tionghoa. Wakil Direktur Promosi Harian Fajar, Ihsan DJ mengatakan bahwa salah satu sumber pemasukan iklan terbesar di Harian Fajar yang berasal dari wilayah Makassar didominasi oleh pengusaha Tionghoa. Sehingga analisis penulis menyatakan bahwa KKP dihadirkan untuk menjaga nilai-nilai idealisme sekaligus bisnis Harian Fajar agar tetap eksis di tengah masyarakat.

"Bijak di Garis Tak Berpihak" pun bukan sekadar slogan Harian Fajar. Rubrikasi dan pemberitaannya telah menunjukkan independensi dan kebijakannya. Sejak terbit pertama pada tahun 1981, Harian Fajar menjadi milik semua golongan. Harian Fajar bahkan berupaya mengangkat derajat dan martabat semua golongan agar tidak ada yang merasa terpinggirkan. Berbagai informasi yang dikemas redaksi, terus diupayakan menjadi kepentingan semua golongan. Pluralitas terus dijaga melalui moto tersebut. (Company Profile Harian Fajar, 2016). Hal ini juga dipertegas dengan apa yang dikatakan oleh Manager Promosi Harian Fajar, Ramah Praeska:

"Kawasan ini kami buka salah satu tujuannya untuk mendekatkan warga pribumi dan warga Tionghoa. Karena kawasan itu berada di Jalan Bali dan Jalan Bonerate, Kecamatan Wajo dan dekat dengan permukiman warga pribumi. Sejak dibuka, kawasan ini semakin ramai. Sudah banyak pedagang. Sekitar 100 pedagang. Ada 40 persen pedagang Tionghoa dan sisanya adalah etnis pribumi. Sehingga kawasan ini menjadi culture street, karena kerukunan agama bisa terwujud lewat KKP ini. (Wawancara 4 Maret 2018). Penerapan metode analisis wacana terlihat pada pemberitaan KKP. Metode analisis wacana lebih menekankan konstelasi kekuatan yang terjadi pada proses produksi dan reproduksi makna. Maksud dari hal ini, individu tidak lagi dianggap sebagai subjek yang netral, yang dengan bebasnya dapat menafsirkan makna sesuai dengan keinginannya, mengingat adanya pengaruh dari kekuatan-kekuatan sosial. Dengan ungkapan lain, menurut Littlejohn (1996), metode analisis wacana 
lebih memperhatikan problem yang ditimbulkan oleh suatu pesan isi komunikasi dengan mengabaikan ciri psikologis yang tersembunyi di baliknya. (Wibowo, 2018).

Jika diamati, analisis discourse practice dalam pemberitaan KKP ini, memusatkan perhatian bagaimana produksi dan konsumsi teks tersebut berlaku. Teks dibentuk lewat suatu praktik diskursus, yang akan menentukan bagaimana teks tersebut diproduksi. Misalnya wacana jurnalisme keberagaman di KKP. Wacana tersebut terbentuk lewat suatu praktik diskursus yang melibatkan bagaimana hubungan antara kaum minoritas etnis Tionghoa dengan warga pribumi di KKP, bagaimana interaksi jual beli antara warga pribumi dan warga Tionghoa, bagaimana dua etnis tersebut menyatu dalam lomba karaoke lagu-lagu perjuangan di momen HUT RI, dan sebagainya. Pola hubungan yang demokratis dimana etnis Tionghoa dan pribumi dapat menunjukkan ekspresinya secara bebas lewat lagu-lagu perjuangan kemerdekaan RI, tentu akan menghasilkan wacana yang berbeda jika itu terwujud di KKP. Semua praktik tersebut adalah praktik diskursus yang membentuk wacana.

Hal yang sama terjadi pada media. Teks berita melibatkan praktik diskursus yang rumit dan kompleks. Praktik wacana inilah yang menentukan bagaimana teks tersebut terbentuk. Dalam pandangan Fairclough, ada dua sisi dari praktik diskursus tersebut. Yakni produksi teks (di pihak media) dan konsumsi teks (di pihak khalayak). Jadi, kalau ada teks media yang mengangkat posisi etnis Tionghoa, kita harus mencari tahu bagaimana teks tersebut diproduksi dan bagaimana juga teks tersebut di konsumsi. Kedua hal tersebut berhubungan dengan jaringan yang kompleks yang melibatkan berbagai aspek praktik diskursif.

Dari berbagai faktor yang kompleks tersebut, setidaknya ada tiga aspek yang penting. Pertama, dari sisi individu wartawan itu sendiri. Kedua, dari sisi bagaimana hubungan antara wartawan dengan struktur organisasi media, baik dengan sesama anggota redaksi maupun dengan bidang lain dalam satu media. Ketiga, praktik kerja/rutinitas kerja dari produksi berita mulai dari pencarian berita, penulisan, editing sampai muncul sebagai tulisan di media. Ketiga elemen tersebut merupakan keseluruhan dari praktik wacana dalam suatu media yang 
saling kait dalam memproduksi suatu wacana berita. (Eriyanto, 2017).

Di sini terlihat bagaimana Muhlis Majid, reporter KKP lebih dahulu dibekali pemahaman jurnalisme keberagaman dalam meliput kasus yang melibatkan antar etnis. Sehingga ketika tiba di lapangan, maka reporter cenderung mencari sudut pandang peliputan yang mengarah pada pemberitaan positif. Seperti pembauran, penyatuan antar etnis, semangat kebersamaan atau pun kekompakan yang terjadi antar warga pribumi dan Tionghoa di KKP. Reporter cenderung menghindari pemberitaan yang bisa menimbulkan konflik antar etnis. Meski pun kenyataannya, selama KKP dibuka, Muhlis mengakui tidak pernah menemukan kasus keributan antar dua etnis tersebut.

Hubungan yang dibangun antara Muhlis Majid dengan Amrullah (editor) dan Ramah Praeska (Manager Promosi Harian Fajar) adalah hubungan profesional yang berbasis moto Bijak di Garis Tak Berpihak. Amrullah sebagai editor selalu mengingatkan kepada reporter untuk menghindari pemberitaan yang bisa memancing kerusuhan akibat SARA. Sementara, Ramah Praeska, sebagai Manager Promosi Harian Fajar juga tidak henti berpromosi bahwa sejak KKP dibuka, semakin banyak pedagang dan pengunjung yang mengisi kawasan ini. Ketiga unsur ini sinergi dalam mempengaruhi pengemasan produksi berita. Berbagai informasi yang dikemas redaksi, diupayakan menjadi kepentingan semua golongan. Pluralitas terus dijaga melalui moto tersebut. Sehingga ketika berita tersebut dikonsumsi, maka pembaca diharapkan memiliki perspektif positif dan tertarik berkunjung ke KKP. Mereka melihat dan merasakan langsung bagaimana pembauran etnis terjadi lewat kawasan yang menjajakan kuliner. Seperti yang dialami oleh beberapa pengunjung:

"Saya tahu KKP karena sering muncul beritanya di Harian Fajar. Lalu coba tanya keluarga dan teman yang sudah pernah ke sini. Mereka bilang bagus, akhirnya saya juga tertarik. Dan malam ini, saya baru pertama kali melihat langsung," (Wawancara Jun Katharina, warga Tionghoa/pengunjung, Sabtu, 10 Maret 2018)

Komentar lainnya:

"Tempatnya bagus. Banyak etnis berkumpul. Harusnya seperti ini karena sebenarnya di Malaysia tempat begini berkumpul etnis di satu tempat kuliner. Harusnya diperbanyak saja tempat kuliner begini. Tidak ada batasan 
siapa mayoritas dan siapa minoritas apalagi makanannya kan umum semuanya halal. Ini bisa jadi daya tarik wisata kita. Saya lihat datang ke sini juga ada tadi satu dua orang bule," (Wawancara Hendra, pengunjung, Sabtu, 10 Maret 2018)

Dari dua tanggapan pengunjung di atas, boleh dikata kemasan berita KKP berhasil membangun citra positif di mata pengunjung. Mereka akhirnya tertarik ke kawasan kuliner tersebut untuk membuktikan suasana seperti yang digambarkan dalam berita. Oleh karena itu, kontinuitas pemberitaan KKP di Harian Fajar yang berkonten positif dan menarik memengaruhi intensitas pengunjung ke KKP. Sekaligus hal ini membuktikan bahwa tidak selamanya bad news is the best news tetapi good news is the best news pun memiliki nilai berita yang kuat.

Selain tingkatan teks dan analisis discourse practice, kerangka analisis wacana kritis Fairclough juga berusaha menghubungkan antara analisis teks pada level mikro dengan konteks sosial yang lebih besar, dalam hal ini sosiocultural practice. Pada tahap analisis, ketiga tahapan itu dilakukan secara bersama-sama. Analisis teks bertujuan mengungkap makna, dan itu bisa dilakukan di antaranya dengan menganalisis bahasa secara kritis. Discourse practice mengantarai teks dengan konteks sosial budaya (sociocultural practice). Artinya, hubungan antara sosiobudaya dengan teks bersifat tidak langsung dan disambungkan dengan discourse practice. Seperti dalam pemberitaan KKP, tidak lepas dari pentingnya editor memiliki mindset jurnalisme keberagaman. Hal ini diakui oleh Amrullah, editor KKP.

"Biar media itu tidak dianggap provokasi, jadi keberagaman selalu dikedepankan. Di Indonesia, isu SARA sangat mudah memicu konflik, jadi sepatutnya media mengedepankan hal-hal ini. Kita berusaha ciptakan kawasan pecinan itu bukan hanya milik orang Tionghoa tetapi semua masyarakat. Karena tidak jauh dari lokasi juga ada kampung Arab. Juga pengalaman kasus pengganyangan Tionghoa di tahun 1990-an di Makassar, kita harap hal itu tidak terulang" (Wawancara dengan Amrullah, 3 Maret 2018).

Jika ditelusuri sejarah, kerusuhan berbalut rasial pernah bergolak pada September 1997. Pada 15 September, yang disebut "September Berdarah" oleh media-media, nasib nahas Ani Mujahidah Rasunnah, bocah berusia sembilan tahun, akibat ditebas parang Benny Karre memicu kemarahan yang meluas. Benny, orang dengan masalah kesehatan jiwa tetapi kebetulan seorang Tionghoa, 
dibingkai "oleh pihak-pihak tertentu, orang-orang tak bertanggungjawab, untuk memancing air keruh," tulis Ratna Kustiati dan Fenty Effendi dalam Agum Gumelar: Jenderal Bersenjata Nurani (2004: 61-62). (https://tirto.id/makassarrusuh-duluan-sebelum-1998-cKFM).

Benny rupanya punya juga rekan-rekan Cina yang merupakan geng Cina di Veteran Selatan. Namun apa daya, massa pribumi lebih besar. Malam itu Benny terbunuh, 500 orang lebih warga Cina terluka. sekitar 3000-an orang mulai melakukan perusakan rumah-rumah dan toko-toko warga keturunan di Jalan Kumala, Ratulangi, dan sekitarnya. Massa kemudian bergerak ke Jalan Veteran, Penghibur, Nusantara, Timor, Sulawesi, Ahmad Yani dan Jalan Wahidin Sudirohusodo sambil melakukan pengrusakan, pelemparan dan pembakaran terhadap kendaraan dan rumah penduduk Cina. Peristiwa itu berbuntut aksi penjarahan pada toko-toko milik warga Tionghoa. Harian Suara Pembaharuan edisi 19 September 1997 menulis kerugian akibat kerusuhan itu mencapai Rp17,5 miliar, 2000 rumah dan toko hancur, 80 mobil rusak, 150 sepeda motor ludes, lima orang tewas, 13 mahasiswa mengalami luka tembak. (https://dm1.co.id/ahok-perlu-berkaca-kerusuhan-makassar-1997/)

Berkaca dari peristiwa di atas, media massa memiliki peran ganda dalam menciptakan kedamaian sekaligus memperkeruh konflik lewat berita yang diproduksinya. Kerusuhan rasial bisa tereduksi jika wartawan mampu melihat persoalan berbau SARA secara bijak dan menuliskan laporannya yang bertujuan untuk mendamaikan pihak yang berkonflik. Namun, jika wartawan tidak memiliki pengetahuan akan pentingnya kemajemukan, maka dengan mudah wartawan dapat menuliskan berita yang justru mempertajam konflik sehingga wartawan menjadi provokator dari peristiwa itu sendiri. Adakalanya, wartawan hanya berpikir pendek demi mengejar rating pemberitaan atau jumlah readership dengan membesar-besarkan berita konflik. Tanpa menghindari fakta yang terjadi di lapangan, perlu kiranya wartawan mengasah daya empati dan menempatkan posisi jika berada di pihak korban akibat berita tersebut. Sehingga tidak asal menulis berita tanpa konfirmasi dan analisis yang tajam. Oleh karena itu, penting kiranya media massa diisi oleh SDM-SDM yang berperspektif jurnalisme keberagaman 
demi menjaga kerukunan dan kedamaian di negara Indonesia yang majemuk dan plural.

\section{SIMPULAN}

Penerapan jurnalisme keberagaman menjadi keniscayaan bagi media massa di Indonesia mengingat bahwa Indonesia merupakan negara majemuk dengan tingkat pluralitas tinggi. Hal ini dilakukan untuk mencegah timbulnya konflik sosial yang lebih luas akibat pemberitaan berbau isu SARA dan gender. Sebagai panglima informasi, setiap jurnalis perlu berperspektif jurnalisme keberagaman, yakni jurnalisme yang menolak diskriminasi etnis, ras, gender, dan agama serta menentang radikalisme, intoleransi, dan ekslusivisme. Jika awak redaksi memiliki perspektif ini, mereka cenderung lebih hati-hati dan selektif menurunkan berita berbau SARA. Apa yang dilakukan oleh Harian Fajar lewat Kawasan Kuliner Pecinan (KKP) patut diapresiasi. Mulai tingkat tataran di lapangan hingga aplikasi lewat pemberitaan, Harian Fajar konsisten menerapkan jurnalisme keberagaman. KKP kini dikenal sebagai kawasan kuliner yang menciptakan pembauran antaretnis sehingga tercipta perdamaian bagi masyarakat setempat.

Hipotesis penelitian ini menyatakan, jika wacana jurnalisme keberagaman dalam pemberitaan KKP diterapkan di Harian Fajar, maka akan menciptakan perdamaian antaretnis pribumi dan Tionghoa. Dengan menguji dua teori yakni agenda setting dan analisis wacana kritis, hipotesis tersebut terbukti. Kawasan ini telah menjadi kawasan kuliner berbasis etnik yang selalu ramai dikunjungi setiap Sabtu malam. Lewat konsistenan Harian Fajar memberitakan, maka pengunjung tidak pernah sepi. Dan, hal ini memang menjadi agenda setting Harian Fajar lewat rapat editorial yang terealisasi pada konten berita. Setelah ditelusuri lewat "realitas" jurnalisme keberagaman di balik teks, peneliti menemukan adanya kepentingan bisnis dan idealisme dari Harian Fajar sendiri terhadap KKP tersebut.

\section{DAFTAR PUSTAKA}

Kansong, Usman. 2016. Jurnalisme Keberagaman. MI Publishing, Jakarta Badara, Aris. 2014. Analisis Wacana; Teori, Metode, dan Penerapannya pada Wacana Media. Kencana Prenada Media Group, Jakarta Ecip, Sinansari. 2007. Jurnalisme Mutakhir. Republika, Jakarta Eriyanto. 2017. Analisis Wacana; Pengantar Analisis Teks Media. LKiS, Yogyakarta 
Iskandar, Maskun-Atmakusumah. 2009. Panduan Jurnalistik Praktis; Memahami Penulisan Berita dan Feature, Memahami Etika dan Hukum Pers. Lembaga Pers Dr. Soetomo, Jakarta

Mulyana, Deddy. 2007. Metode Penelitian Komunikasi, Contoh-contoh Penelitian Kualitatif dengan Pendekatan Praktis. Remaja Rosdakarya, Bandung

Santana K, Septiawan. 2017. Jurnalisme Kontemporer. Yayasan Pustaka Obor Indonesia, Jakarta

Severin, Werner J-Tankard Jr, James W. 2005. Teori Komunikasi; Sejarah, Metode, dan Terapan di Dalam Media Massa. Prenada Media, Jakarta Titscher, Stefan, dkk. 2009. Metode Analisis Teks \& Wacana. Pustaka Pelajar, Yogyakarta

Wibowo, Wahyu. 2018. Komunikasi Kontekstual. PT Bumi Aksara, Jakarta

\section{Jurnal Ilmiah:}

Hamad, Ibnu. 2007. Lebih Dekat dengan Analisis Wacana. Mediator. Vol. 8. No. 2 Mayopu, Richard G. 2015. Jurnalisme Antar Budaya Sebagai Jalan Menuju Toleransi Berbangsa dan Bernegara. Pax Humana.Vol. II, No. 3

Ritonga, Elfi Yanti. 2018. Teori Agenda Setting dalam Ilmu Komunikasi. Simbolika. Vol. 4 (1)

Buklet:

Company Profile Harian Fajar edisi tahun 2016

\section{Koran:}

Harian Fajar, 12 Maret 2016

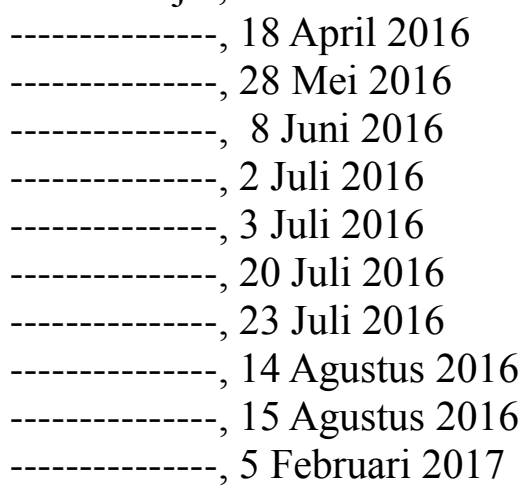

\section{Internet:}

https://tirto.id/makassar-rusuh-duluan-sebelum-1998-cKFM https://dm1.co.id/ahok-perlu-berkaca-kerusuhan-makassar-1997/ https://www.teras.id/life/pat-2/25205/sejarah-masuknya-etnis-tionghoa-dimakassar 